\title{
Monitoring of Tilia cordata Mill. Planting in the conditions of the city of Abacan
}

\author{
Natalia Kazakova* \\ Khakass State University named after N. F. Katanov, 655017 Abakan, Russia
}

\begin{abstract}
A visual assessment of the condition of Tilia cordata Mill was carried out. for the five-year period from the moment of planting to the present, using the example of the jubilee alley of the city of Abakan in the Chernogorsky Park. It is established that the main factors of negative impact on the state of plantings are: mechanical damage to young plants by park visitors and the influence of arthropods-pests.
\end{abstract}

\section{Introduction}

Small-leaved linden-Tilia cordata Mill. - is an introduced species for Siberia, whose natural habitat is North America [1]. Currently, this plant is used in Khakassia for urban landscaping.The study of the peculiarities of adaptation of small-leaved linden in the conditions of the city of Abakan is very relevant, as it will allow to predict its further development and, if necessary, to take timely care of trees, apply special measures to protect them from diseases and pests. The purpose of our work was to study for five years the peculiarities of the growth of young plantings of $T$. cordata in the conditions of the city of Abakan.

\section{Materials and methods}

The research was carried out in the spring-summer period of 2016-2021 on the territory of the Chernogorsky Park in the city of Abakan. The object of the study was the woody plants of $T$. cordata. The research material was the results of a visual examination of trees. Biometric characteristics of individuals were carried out on the basis of the following characteristics: the height of the plant, the diameter of the trunk at a height of $1.3 \mathrm{~m}$, the condition of the crown, its infection with diseases and pests. A total of 85 individuals (2016 year) to 76 individuals (2021 year) of $T$. cordata were studied. The condition of plantings was determined by the following criteria:" good " - plantings healthy, with a crown, without significant damage;" satisfacteur " - plantings healthy, but with an incorrectly developed crown, with significant, but not life - threatening injuries or injuries;" unsatisfactory " plantings with an incorrect or poorly developed crown, with significant damage, injuries, infection with diseases or pests that threaten their life.

\footnotetext{
* Corresponding author: goloshapova07@mail.ru
} 


\section{Results and discussion}

Both native and introduced species are found in the assortment of plantings of the city of Abakan [2-3]. At the expense of introducers, it is possible to enrich the species composition of urban green spaces, which in general creates a comfortable environment for people's life, not only by improving environmental conditions, but also in architectural, planning and aesthetic terms. Optimization of urban landscaping requires a differentiated selection of plants that combines their decorative qualities, stability in the urban environment and the ability to perform environmental-forming functions [4]. The success in creating effective green spaces largely depends on the correct selection of breeds using non-district ones that are able to heal the environment and preserve decorativeness for a long time [5]. Currently, poplar (Populus nigra L., P. laurifolia Ledeb.) plays a leading role in the landscape appearance of the green areas of Abakan. Basically, these are powerful trees of 50-60 years old, planted spontaneously (during mass planting- Sabbatarian), simultaneously with the construction of the city. The branches of old poplars easily break off in strong winds and fall on the roadway. In addition, the mass planting of poplars carries the risk of simultaneous death of plants at the end of their life cycle or as a result of disease damage. It is planned that in the future, lime alleys will gradually replace old poplars in the city of Abakan. It is for this purpose that the studied T. sordata trees were planted in a replacement way next to poplars in the Cernogorsky Park of the city in May 2016 for the 85th anniversary of the city of Abakan. There are also previously planted plants of $T$. cordata in the city, but they are isolated and few in number. The planting of $T$. cordata plants studied by us was carried out in accordance with the construction norms of the rules of SP 42.13330.2016 "SNiP 2.07.01-89 Urban planning. Planning and construction of urban and rural settlements". When planting, the phytocenotic principle of the recommended combination of plants in urban planting was also taken into account [4]. All the planted lime trees belonged to the same age category, corresponding to three years.

The initial data for monitoring observations were obtained two months later (July 2016) from the date of planting. The conducted studies showed that all the plants remained viable at the time of their examination. $78 \%$ of lime trees were in good condition, $20 \%$ of trees were satisfactory, $2 \%$ were unsatisfactory. Most of the plants $(67 \%)$ had one trunk, $20 \%$ had two trunks, $11 \%$ had three trunks, $2 \%$ had four trunks. The minimum diameter of the trunk at a height of $1.3 \mathrm{~m}$ was $-1 \mathrm{~cm}$, the maximum $-5 \mathrm{~cm}$. Absolutely all $T$. cordata individuals had damage to leaf blades in the form of felt (100\% of plants) or horns $(16 \%$ of plants). Galls in the form of felt were located above, less often below in the form of white or reddish, later brown spots, were caused by Eriophyes tiliae var. liosoma Nal., E. tiliae var. rudis $\mathrm{Nal}$. it formed galls in the form of horns on the upper side of the leaves.

A survey of linden plantings in 2017 showed that $2 \%$ of the plants completely lost their viability and dried up. $5 \%$ of lime trees were damaged due to the anthropogenic factor, had broken trunks. $93 \%$ of linden trees were in good condition, and $2 \%$ of them were perfectly healthy, without any visible external damage to the leaf blades. The maximum height of the trees in the plantings was $285 \mathrm{~cm}$, the minimum $-110 \mathrm{~cm}$. The maximum diameter of the barrel was $9 \mathrm{~cm}$, the minimum $-2 \mathrm{~cm}$. Among the pests on the leaves of lime trees $(11 \%$ of plants), there was an aphid Eucallipterus tiliae L., which released honeydew, which contributed to the sticking of dust on the leaves. E. tiliae var. liosoma was present, E. tiliae var. rudis was also found, not previously found in plantings of Eriophyes tetratrichus Nal., contributing to the curvature and thickening of the leaves up along the edge.

In 2018 , the inventory of trees showed that some of them $(9.4 \%)$ were subjected to sanitary felling by the city services, because they turned out to be unviable. Basically, these were plants that grew near the pathways and suffered from mechanical damage of an anthropogenic nature. To reduce the degree of mechanical damage, some of the plants (15 
pcs.) were equipped with wooden protective fences. The number of plant trunks has changed compared to 2016 . So $84 \%$ of lime trees had one trunk, the rest had two. There are no plants with three and four trunks left in the plantings. The maximum height of the plant in the linden plantings in 2018 was about $310 \mathrm{~cm}$, the minimum $-85 \mathrm{~cm}$ (due to the breakdown of the trunks). The assessment of the state of plantings in 2018 allowed us to distinguish three categories of plants: 1) with a good condition-42 \%, 2) with a satisfactory $39 \%, 3$ ) unsatisfactory-19\%. The damage to the leaves is associated with the presence of such injuries as gnawing and galls on them. $100 \%$ of the plants were damaged by E. tiliae var. liosoma. Other pests on linden leaves were also noted: Eriophyes tiliae var. nervalis Nal., E. tetratrichus, E. tiliae,

In 2019, the general condition of most lime trees was assessed as good. About $17 \%$ of the plants had small, wilting or unformed leaves. The maximum height of the lime trees left $327 \mathrm{~cm}$, the minimum-37 cm (due to the broken trunk). Some of the lime trees that were broken earlier began to recover, forming new young shoots. The maximum diameter of the barrel was $10 \mathrm{~cm}$, the minimum $-3 \mathrm{~cm}$. The main pests of leaf blades this year were: $E$. tiliae var. nervalis, E. tiliae var. liosoma, E. tiliae, E. tetratrichus.

By 2020, in the linden alley plantings, the condition of most linden trees in the plantings can be assessed as good (47\%), for $36 \%$ of plants as satisfactory, $17 \%$ of linden trees were characterized by an unsatisfactory condition. Four plants were cut down due to death, the cause of which was still an anthropogenic factor. The list of primary pests of $T$. cordata was slightly expanded in 2020. For the first time, E tiliae var.liosoma, E. tiliae var. nervalis, Eriophyes tiliae var.exilis Nal., were found on leaf blades, which formed galls in the form of small rounded bulges in the corners of the veins on the upper side of the leaf. The gnawing was caused by the larvae of Pristiphora ruficornis Ol sawflies. The aphid Eucallipterus tiliae was present on the leaf blades. The maximum height of the trunk was $360 \mathrm{~cm}$, the minimum $-15 \mathrm{~cm}$. The diameter of the trunk is from $3 \mathrm{~cm}$ to $16.4 \mathrm{~cm}$

As of June 2021, the studied linden plantings were dominated by individuals with a good condition ( $83 \%$ ), the share with satisfactory accounted for $13 \%$, unsatisfactory $-4 \%$. Lime trees with an unsatisfactory condition were characterized by broken trunks. The maximum diameter of the barrel was $17 \mathrm{~cm}$, the minimum-3.5 cm. The main gall - forming pests were: E. tiliae var. nervalis, E. tiliae var. liosoma. E. tiliae vak. rudis, E. tetratrichus .

\section{Conclusion}

The conducted studies allow us to draw conclusions that $T$. cordata can continue to be used in artificial plantings in the city of Abakan. During the five-year observation period, out of 85 plants planted, 9 died. The main cause of plant death is probably due to the influence of an anthropogenic factor, but the viability of lime trees could also be affected by the process of natural drying of plants in the first years from the moment of their planting. The growth rate of different plant individuals in the plantings differed to a greater or lesser extent. The growth of $T$. cordata in good condition for 2019-2020 was about 0,31 m, the trunk diameter increased by $3,28 \mathrm{~cm}$. Plants susceptible to diseases and pests were characterized by a slight increase. Along with the defeat of the leaf blades of lime trees by pathogenic fungi, there were also injuries caused by arthropods. The most typical primary pests of $T$. cordata were E. tiliae var. liosoma, E. tiliae var.nervalis, E. tiliae. The species diversity of pests in the observed linden plantings increased during the study period, but the level of removal of the leaf surface area was low, which is probably due to the lack of formation of consort relationships of arthropods-primary pests with the non-local species $T$. cordata. As recommendations, we can offer urban landscaping services to organize a system of care for $T$. cordata plantings in order to strengthen the ecological potential of plantings. It is 
necessary: constant inventory of $T$. cordata plantings, timely care of the crown of trees, pest and disease control, watering, fertilizing plants, soil care and protection of plants from mechanical damage by park visitors.

\section{References}

1. N. A. Babich, O. S. Zalyvskaya, G. I. Travnikova, Introducents in green construction of northern cities (Arkhangelsk, 2008)

2. E. G. Lagunova, O. A. Vasileva, Problems of Botany of Southern Siberia and Mongolia, 15 (2016)

3. E. Yu. Zhukova, E. G. Lagunova, BIO Web Conferences 16 (2019).

4. I. L Bukharina., A. A. Dvoeglazova, Bioecological features of herbaceous and woody plants in urban plantings (Izhevsk, 2010).

5. E. M. Runova, P. S. Gnatkovich, G. L. Zolotuklina, Systems. Methods. Technologies. 3 (27) (2015) 